\title{
IMPLEMENTATION OF LEGAL AID TO DEBTORS DUE TO ARREARS IN MOTOR VEHICLE INSTALLMENTS EXECUTED BY DEBT COLLECTORS AS IMPACT OF THE COVID-19 PANDEMIC
}

\author{
Widya Kurnia Sulistyowati \\ Universitas Negeri Semarang, Indonesia \\ *Email: widyakurniasulistyowati@students.unnes.ac.id
}

Based on Law No. 16 of 2011 on Legal Aid, Article 1 paragraph (1) states that Legal Aid is a legal service provided by legal aid providers free of charge to Legal Aid Recipients. Legal aid is a guarantee of legal protection and a guarantee of equality before the law, which is a constitutional right for every citizen. Because, the constitution guarantees the right of every citizen to get equal treatment before the law, including the right to access justice through legal aid. Due to the Covid-19 pandemic, many people are asking for legal assistance related to the case of installment billing by debt collectors. Debt collector itself is a third party, which has an agreement with the financing institution to

The Indonesian Journal of International Clinical Legal Education DOI: https://doi.org/10.15294/ijicle.v3i4.48295

Submitted: Dec 12, 2020 Revised: March 13, 2021 Accepted: August 10, 2021 Available online at https://journal.unnes.ac.id/sju/index.php/iccle (c) 2021 Authors. This work is licensed under a Creative Commons AttributionShareAlike 4.0 International License (CC BY-SA 4.0). All writings published in this journal are personal views of the authors and do not represent the views of this journal and the author's affiliated institutions. 
Widya Kurnia Sulistyowati

make efforts to force the collection of debtor vehicles because it has not paid installments as agreed. The result of this paper is that under these circumstances there is another legal remedy, namely restructuring.

Keywords: Legal Aid, Debtors, Bad Loans, Debt Collectors.

\section{INTRODUCTION}

The Covid-19 pandemic in Indonesia, of course, not only has an impact on health, but also has an impact on several fields, one of which is the economy. The economy in Indonesia is also affected. The banking sector and financial institutions are among those affected by this pandemic. Since the emergence of cases of the corona virus in Indonesia, the economy in Indonesia has fallen drastically. In the Constitution we have mandated how the economy in Indonesia is run. This is contained in Article 33 of the Indonesian Constitution which is the basis of the economy in Indonesia. The article reads: ${ }^{1}$

(1) "The economy is structured as a joint effort based on the principle of kinship.

(2) Production branches which are important to the state and which affect the livelihood of the people are controlled by the state.

(3) The earth and water and the natural resources contained therein shall be controlled by the state and used for the greatest prosperity of the people.

(4) The national economy is organized based on economic democracy with the principles of togetherness, efficiency with justice, sustainability, environmental insight, independence, and by maintaining a balance of progress and national economic unity.

(5) Further provisions regarding the implementation of this article shall be regulated in law."

In this article, it is very clear that the state must support the welfare and prosperity of its citizens. It has been more than a year since the COVID-19 pandemic has not ended. Starting from March 2020 until now in July 2021. Of course, the pandemic has several negative impacts, one of which is causing concern and fear in the community. The existence of the covid-19 pandemic has resulted in various joints of life being paralyzed, not only in the health sector which we all know has taken quite a number of victims, but also of course has an impact on the activities of the economic sector, resulting in various financial problems appearing, especially in the banking sector. financial institutions. The banking sector and financial institutions are one of the various problems in the financial sector that have been affected by the COVID-19 pandemic. The impact

1 Undang - Undang Dasar Negara Republik Indonesia Tahun 1945 
of the COVID-19 virus pandemic on the banking industry and financial institutions in each segment is certainly different. Banking itself is all aspects related to activities regarding bank institutions. As for the bank itself is an industry that is engaged in the financial sector, meaning that banking activities are always related to the financial sector. ${ }^{2}$

The Covid-19 pandemic also has legal implications for the parties to conduct a review of the contents of the contract which turns out to be no longer in accordance with current conditions. With negotiations, the parties will inevitably give birth to new forms of agreement that take into account the problems and interests of each party. This Covid-19 pandemic certainly has a major impact on industry revenue or income in the banking sector and financial institutions, but of course the impact will be different for each customer. The impacts commonly faced by financial institutions today are credit risk, market risk, and operational risk. As a result of the impact of the Covid-19 pandemic, of course, the banking sector and financial institutions related to the financial sector issue policies related to delaying credit payments for customers. ${ }^{3}$

Industrialization activities are a process of economic modernization which includes all economic sectors related to each other with the manufacturing industry. This means that industrialization aims to increase added value in all economic sectors with the manufacturing sector as the main sector. That is, with the development of the industry it will spur and lift the development of other sectors. ${ }^{4}$ In business transactions, default often occurs which of course has a broad impact on business planning so that it can harm financial and non-financial aspects such as goodwill and business trust. The legal consequence of default is that the party who is unable to carry out the agreement must be responsible for compensating for the loss of the object that was agreed upon at the beginning. ${ }^{5}$

At the present time, various kinds of vehicle products are offered by motor vehicle companies which of course have given the interest of the urban community to immediately have a vehicle that has become the target of consumers. These luxury goods are no longer something strange to have for those who need a vehicle for daily mobility. The emergence of such a thing, of course, becomes a field for financial institution

2 Ardiansyah Putra dan D. Saraswati, Bank Dan Lembaga Keuangan Lainnya, CV. Jakad Media Publishing : Surabaya, 2020, p. 21.

3 Ratna Desinta Mega Kumala, "Legal Analysis of Government Policy on Large Scale Social Restrictions in Handling Covid-19." The Indonesian Journal of International Clinical Legal Education Vol. 2 No.2, 2020, pp. 181-200; Mutiara Hamdalah Munandar, "Analysis the effectiveness of tax relaxation due to Covid-19 pandemy on Indonesian economic defense." Lex Scientia Law Review Vol. 4 No.1, 2020, pp. 125-133.

4 Arsyad Lincolin, Ekonomi Pembangunan, STIE YKPN. Yogyakarta, 2014.

5 Aminah, Pengaruh Pandemi Covid-19 Pada Pelaksanaan Perjanjian, Diponegoro Private Law Review, 2020, pp. 650 - 656. 
companies to cooperate with motor vehicle manufacturers in terms of providing credit facilities and easy installments at relatively low costs to debtors who want to own a vehicle but have limited finances. After the credit process takes place, in conditions like this, of course, there are many obstacles and problems that occur, starting from the frequent negligence of the debtor in fulfilling the obligation to pay monthly installments as agreed with the financial institution company and even forced circumstances such as the Covid-19 pandemic that made the debtor unable to do so. able to fulfill its obligations which makes the company inevitably have to withdraw the vehicle to pay off the installments with the help of debt collectors. ${ }^{6}$

The phenomenon of forcibly collecting motor vehicle bad loans by debt collectors at the behest of financial institutions often makes debtors restless. Prior to the COVID-19 pandemic, there were 3 (three) formulations of the occurrence of bad loans that often occurred, including: ${ }^{7}$

a) loans whose principal and interest installments cannot be repaid for more than two installments plus 21 months;

b) the settlement has been submitted to the court/BUPLN;

c) the settlement has been submitted for compensation to the credit insurance company.

The term debt-collector comes from English, namely debt and collector. Debt means debt and collector means collector. The Debt Collector is considered to reflect collection criteria that prioritize acts of violence and is considered inappropriate for use in financial institutions in Indonesia. Debt-collector is a third party, which has an agreement with a financial institution to make efforts to force the taking of the debtor's vehicle because it has not paid the installments as agreed. Debt-collectors are often considered by the public as collectors who use violence, so that inevitably the debtor must hand over the vehicle that is still in installments to a financing institution as long as the debtor has not paid off the installments.

The impact of the COVID-19 pandemic has made creditors unable to fulfill their obligations to pay off their installment bills. So that many people ask for legal assistance regarding debt collector bills, this happens because not a few people are caught in arrears in installments, especially motor vehicle installments. According to the Secretary General of LKBH

6 Ika Atikah. "Perusahaan Leasing dan Debt Collector Dalam Penagihan Kredit Macet Kendaraan Debitur". Jurnal ADALAH : Buletin Hukum dan Keadilan. Volume 2 Nomor 8c. 2018. p 7. See also Widi Nugrahaningsih, and Indah Wahyu Utami. "Perlindungan Bagi Debitur Penerima Fasilitas Kredit Dimasa Pandemi Covid 19." Jurnal Indonesia Sosial Sains Vol. 2 No.3, 2021, pp. 484-493; Stacey Salters, "Debt-Collection Reforms Draw Congressional Focus Post-COVID." American Bankruptcy Institute Journal Vol. 40 No.7, 2021, pp. 8-55.

7 Abdulkadir Muhammad, Hukum Perusahaan Indonesia, cet. ke-4, revisi, Bandung, PT. Citra Aditya Bakti, 2010, p. 321. 
(Institute for Legal Studies and Aid) Djoeang Indonesia During this pandemic, his party has helped quite a few people who are caught in arrears on motor vehicle installments. In particular, those who were fired or their businesses were forced to go out of business so that they could not pay the vehicle installments. In providing legal protection to debtors, this LKBH has provided legal protection to 20 to 30 for debt collector billing cases. ${ }^{8}$

As a result of this pandemic, it will certainly cause a forced situation where people are unable to pay their installment bills. For those who have sufficient funds, it is certain that they will not achieve this kind of problem, but for people who are weak in terms of the economy and in terms of legal knowledge, it will certainly be difficult to get legal assistance when they have to deal with legal cases. The issue of the COVID-19 pandemic is certainly difficult for debtors and creditors, in this case, financial institutions. For debtors themselves, there are many factors that cause them to not be able to pay their installment bills, especially from an economic perspective, the issue of losing their job is also a trigger for debtors not being able to fulfill their obligations. people are often unable to pay their installments, especially to pay for legal defense services because of cases of execution of motorized vehicles by debt collectors, of course this will be a very complex problem. From the background that has been described so that it becomes the author's reason to discuss the Implementation of Legal Aid Against Debtors Due to Arrears of Motor Vehicle Installments Executed by Debt Collectors as an Impact of the Covid -19 Pandemic to find out the causes, solutions and also the impact on creditors and debtor. ${ }^{9}$

8 Indah Handayani. 2021. Pandemi Covid-19, Masyarakat Banyak Minta Bantuan Hukum Soal Debt Collector. https://www.beritasatu.com/nasional/733275/pandemi-covid19-masyarakatbanyak-minta-bantuan-hukum-soal-debt-collector di akses pada Senin, 15 Februari 2021.

9 The number of debtors who have difficulty paying credit has increased during the COVID-19 pandemic. PT Pemeringkat Efek Indonesia (Pefindo) stated that the number of debtor profiles in the high and very high risk categories continued to grow, reaching $45.2 \%$ as of July 2020, including commercial banks, rural banks and finance companies. For comparison, as of December 2019 the figure was only $41.2 \%$. The pandemic affects the ability to pay which causes changes in the risk profile of debtors and causes an increase in NPL (non-performing loans, nonperforming loans). Data from the Financial Services Authority (OJK) showed gross NPL as of December 2019 was only $2.53 \%$ and rose in March to $2.79 \%, 3.11 \%$ in June, and $3.22 \%$ as of August. See also Peter Garlans Sina, "Ekonomi Rumah Tangga Di Era Pandemi Covid-19." Journal of Management: Small and Medium Enterprises (SMEs) Vol. 12 No.2, 2020, pp. 239-254; Fatkhur Rohman Albanjari, Rina Prihatin, and Suprianto Suprianto. "Analisa Dampak Kebijakan Pemerintah Terhadap Kinerja Keuangan Bank Umum Syariah di Indonesia Pada Era Pandemi Corona Virus Disease-19." Musyarakah: Journal of Islamic Economic (MJSE) Vol.1 No.1, 2021, pp. 9-19; Rahmi 


\section{IMPLEMENTATION OF LEGAL AID TO DEBTORS DUE TO ARREARS IN MOTOR VEHICLE INSTALLMENTS EXECUTED BY DEBT COLLECTORS AS IMPACT OF THE COVID -19 PANDEMIC}

In Law Number 16 of 2011 explaining about Legal Aid, Article 1 paragraph (1) Legal Aid is a legal service provided by Legal Aid Providers free of charge to Legal Aid Recipients. Article 1 paragraph (1) Legal Aid recipients are poor people or groups of people. And article 1 paragraph (3) explains that the Provision of Legal Aid is a legal aid institution or community organization that provides Legal Aid services based on this Law. ${ }^{10}$ In this state of the Covid-19 pandemic, most of the complaints to LBH (Legal Aid Institutions) are via telephone or WhatsApp. But if the situation is urgent, legal assistance is carried out directly by observing health protocols such as using masks, washing hands and/or using hand sanitizers and doing physical distancing. Of course, from LBH the form of services provided can be in the form of litigation such as legal assistance in court or non-litigation such as mediation of complaints reports and others. ${ }^{11}$ During this pandemic, several good practices carried out by LBH include: ${ }^{12}$

1. Optimizing online legal aid services through the case hotline

Online case consultation can be accessed at 0813-8882-2669 via whatsapp message. From the beginning of the pandemic, online legal consultation services started from 09.00 WIB - 21.00 WIB. with the aim that the victim can maximize consultation and wait for the right time, namely when the perpetrator is not at home. From these services through the Legal Services Division, the victim or potential partner will be contacted by the victim's lawyer or companion who will provide litigation and non-litigation legal assistance according to the victim's needs.

2. Strengthening Legal Aid Services carried out by Paralegals in the community

3. Online trial by optimizing Probono Advocates

4. Online Campaign

5. Implementing Work from Home (WFH) Total

Rosita, "Pengaruh pandemi Covid-19 terhadap UMKM di Indonesia." Jurnal Lentera Bisnis Vol. 9 No.2, 2020, pp. 109-120.

10 Undang - Undang Nomor 16 Tahun 2011 Tentang Bantuan Hukum

11 Wide Afriandy et, al. Panduan Bantuan Hukum Selama Pandemi Covid - 19. 2020. pp 4-6.

12 Ibid. 
6. The existence of health protocols and case handling protocols

In addition to good practices, of course in $\mathrm{LBH}$ there are Challenges and Mitigations in carrying out their duties during this pandemic, among challenges and mitigation, among others the challenges of providing legal aid during this pandemic mostly come from external LBH. As has been the case in the past, which relates directly to the mechanism of the trial via teleconference. The biggest challenge is in the technical implementation of the online model trial itself. For example, when the trial started, the parties did not know what application to use. The first time we use the Zoom application, but because we don't use a premium account, it can only be used for about 30 minutes. After that have to use the creation of a new virtual meeting room in the zoom. It is also unfortunate that the panel of judges and public prosecutors are not familiar with online trials and the use of technology-based applications. As a result, the trial took a long time and was only technical. ${ }^{13}$

In handling the case of collection of installments by debt collectors against debtors, legal protection efforts that can be carried out by the Legal Aid Institute in this case there are several provisions. Legal protection itself is the protection of the dignity and worth, as well as the recognition of human rights that have been owned by legal subjects which are also based on legal provisions from arbitrariness. ${ }^{14}$ In this case, financial institutions are also activities engaged in the financial sector so that all their activities are supervised by the OJK (Financial Services Authority). In the period prior to the Covid-19 pandemic, the Financial Services Authority was an independent institution, as well as its function in regulating and supervising the entire financial services sector in Indonesia, the Financial Services Authority had regulations to support the program as well as the vision and mission of the Financial Services Authority. One of the regulations issued is POJK Number 11/POJK 03/2015 concerning Prudential Provisions in the Context of National Economic Stimulus for Commercial Banks. ${ }^{15}$

Prior to the Covid-19 pandemic, which was related to credit made by customers, there were several special policies established by the Financial Services Authority through the Financial Services Authority Regulation Number 11/POJK.03/2015 in which there were several provisions regarding credit restructuring. Credit restructuring itself is an improvement effort carried out by the Bank in credit activities for debtors who have difficulty fulfilling their obligations, which are carried out, among others, in various ways including;

3 Ibid.

14 Philipus M. Hadjon, Perlindungan Bagi Rakyat Diindonesia, Surabaya: Bina Ilmu, 1987, pp. 1-2.

15 Hardiansyah, et.al.,. "Perlindungan Hukum Terhadap Debitur Yang Kesulitan Untuk Memenuhi Kewajiban Dalam Perjanjian Kredit Akibat Pandemi Covid -19”. Jurnal Fakultas Hukum Universitas Islam Malang. 2020. pp. 439-440. 
a. Decrease in loan interest rates;

b. Extension of the term of the Credit;

c. Reduction of loan interest arrears;

d. Reduction of loan principal arrears;

e. Addition of credit facilities; and/or

f. Conversion of credit into temporary equity participation. ${ }^{16}$

Based on the provisions of Article 6 of POJK Number $11 /$ POJK.03/2015, it is stated that the quality of loans that can be restructured is as stated in Article 7 paragraph (1)

letter a, namely for loans classified as doubtful or bad. Then as Article 7 paragraph (1).

letter $b$, namely for loans classified as special attention or substandard.

Thus, based on the POJK Regulation Number 11/POJK.03/2015, the provisions regarding credit restructuring are given to customers in terms of the criteria and quality of customer credit prior to restructuring, as regulated in Article 6 and Article 7. ${ }^{17}$

In the event that if the debtor is unable to pay a debt, it is also referred to as a default, default itself is an act of not fulfilling achievements and being negligent when fulfilling obligations such as the debtor's obligations to creditors as agreed in the contents of the agreement, of course binding the parties, with other meanings wrong one party is harmed and this is not in a state of coercion. ${ }^{18}$ Default arises because of an agreement made by the parties, if in the event that the parties commit a breach of contract or default it is not stated that there is an agreement, then it cannot be declared as a default but an act against the law, considering that basically the concept of the default is an act. irregularities committed by the party, of course, under conditions that are not coercive. ${ }^{19}$

Associated with the case of bad loans where customers and debtors face difficulty in carrying out their obligations in paying debts, they can carry out credit restructuring in banks or the financing industry based on the requirements of Article 2 of the POJK, especially in Article 2 Paragraph (I). For debtors who meet the above requirements until the debtor obtains credit or financing restructuring, as stated in Chapter III of the Financial Services Authority Regulation, it regulates credit

16 Pasal 1 angka 4 POJK Nomor 11/POJK.03/2015 tentang Ketentuan Kehati-Hatian Dalam Rangka Stimulus Perekonomian Nasional Bagi Bank Umum.

17 Ibid.

18 Leonora Bakarbessy \& Anand, G, Buku Ajar Perikatan. Zifatama Jawara.Sidoarjo, 2018, pp 41-42.

19 I Made Rai Sukeerta. "Restrruktusi Kredit Terhadap Debitur Akibat Wanprestasi Karena Dampak Pandemi Covid -19”. Jurnal Preferensi Hukum. Vol. 2 No. 2021. p. 327. 
restructuring or financing. Besides functioning to reduce the burden on debtors, credit restructuring also protects the liquidity of a bank, given the economic situation in the midst of this kind of pandemic. ${ }^{20}$ This policy was created considering that customers are not willing to pay debts and customer obligations to banks as a result of the impact of the corona virus related to the weakening of the community's economy, this is a way issued by the government to protect people's lives when there is a panic against the emergence of problems that occur in the banking sector. With the issuance of this policy, the debtor can apply for a payment suspension or negotiate with the bank if he is affected by the covid-19 pandemic where the aim is to relieve the debtor's obligations in terms of debt payments. ${ }^{21}$

This credit restructuring is carried out as an effort to rescue nonperforming loans which can be done in three ways, namely rescheduling, realigning, and reconditioning. For example, extending the term, reducing interest rates and so on. Credit restructuring can be implemented if the customer has good behavior. Customers who behave well in resolving non-performing loans can be determined from the desire and ability to fulfill obligations in the form of customer attitudes, as follows:

1. The customer must be able to be invited to talk about completing his credit

2. The customer is willing to provide correct financial information

3. The customer must give permission to the bank in terms of carrying out checking of financial information and

4. The customer participates in the non-performing loan security program and implements the methods issued by the bank. ${ }^{22}$

In this case, the settlement of debt carried out by LBH through a court process must be accompanied by a debtor who has a good attitude who can discuss again with the financing institution (in this case the debt collector) regarding the repayment of the debt, which asks for negotiations regarding an extension of time. Usually debt collectors still open the possibility for negotiations because they themselves get part of the bill. Unless the debtor is indeed unable to pay, the debt settlement can only be resolved through a court process.

Regarding the criteria for debtors who meet the provisions of credit restructuring due to the COVID-19 pandemic, it is regulated in POJK 11/POJK. 03/2020, in Chapter III it controls the restructuring of credit or financing Article 5 and Article 6. In Article 5 Paragraph (1) ensuring that

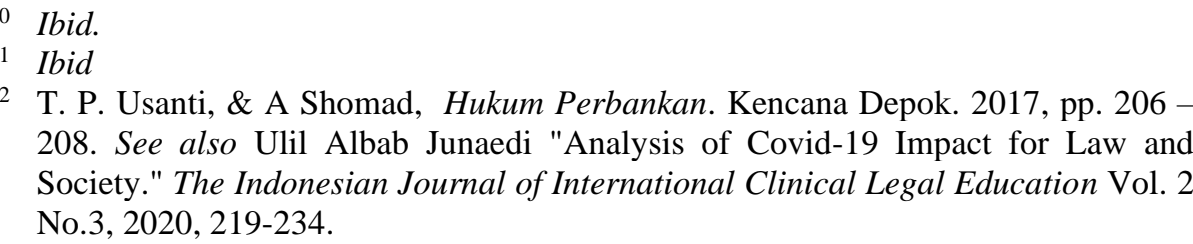


the quality of the restructured credit or financing is inaugurated easy since the restructuring is attempted. This is one of the credit relaxation efforts during the covid-19 pandemic, Article 5 Paragraph (2) banks can provide credit restructuring when debtors apply for credit to banks or financing institutions before or after the formation of the covid-19 pandemic, but in the case of debtors applying for credit when before the covid-19 pandemic occurs, the quality of credit or payment must be declared easy. The credit restructuring applies to small and medium enterprises (SMEs) and includes MSMEs as well, paragraph three where credit for Rural Banks and Islamic Rural Banks depends on the accounting treatment of each bank, Article 6 point a, is given to debtors who comply with the following provisions: Debtors affected by the COVID-19 pandemic include micro, small and medium business debtors, Article 6 point $\mathrm{b}$, will be restructured after customers are declared affected by the onset of the COVID-19 pandemic, including micro, small and medium business customers. Based on the provisions of Article 10 of the OJK Regulation of the Republic of Indonesia above, the validity period is until March 31, 2021. In relation to the COVID-19 pandemic, which has not ended, OJK has re-issued POJK No. 48 / POJK.03/2020 to change POJK rules No. II /POJK.03/2020. The provisions that mention credit restructuring in paragraph three (3) are amended and added to three (3) paragraphs, so that in terms of relaxation the rules are even clearer so that as a customer who wants to do relaxation related to being unable to fulfill his obligations, he will no longer feel doubts because the rules are clearer. ${ }^{23}$

The purpose of the regulation is to consider that the spread of COVID-19 is still occurring both globally and nationally which of course has consequences for debtors and minimizes the risk of bad credit, therefore a regulation is made by the Financial Services Authority to anticipate and optimize performance for banks and can maintain stability and be able to increase economic growth, but must prioritize and use the principle of prudence. ${ }^{24}$

Actually, in handling this case, LBH can use Law Number 42 of 1999 concerning Fiduciary Guarantees. The law explains that fiduciary is the transfer of ownership rights to an object on the basis of trust provided that the object whose ownership rights are transferred remains in the control of the owner of the object. Furthermore, in Article 15 it is stated that in the Fiduciary Guarantee Certificate the words FOR JUSTICE BASED ON THE ALMIGHTY GOD (DEMI KEADILAN BERDASARKAN KETUHANAN YANG MAHA ESA), the Fiduciary Guarantee Certificate has the same executorial power as a court decision

23 I Made Rai Sukeerta. "Restrruktusi Kredit Terhadap Debitur Akibat Wanprestasi Karena Dampak Pandemi Covid -19”. Jurnal Preferensi Hukum. Vol. 2 No. 22021. pp $328-329$.

24 Ibid. 
that has obtained permanent legal force and if the debtor is in breach of contract, the Fiduciary Recipient has the right to sells Objects that are the object of a Fiduciary Guarantee on its own power. Based on the provisions in Law Number 42 of 1999, especially Article 15, there are different interpretations related to the process of executing or withdrawing fiduciary guarantees in the form of motorized vehicles if the credit is non-performing. Some interpret that the process of withdrawing a motor vehicle must go through the courts, but some consider that based on the authority granted by the law, it can make a withdrawal on its own or unilaterally, and this is what then happens in the community for forced withdrawal of motorized vehicles by debt collectors.

\section{ACCOUNTABILITY OF THE DEBT COLLECTOR DUE TO THE EXECUTION OF ARREARS ON MOTOR VEHICLES OWNED BY THE DEBTOR AS AN IMPACT OF THE COVID-19 PANDEMIC}

In the world of finance or leasing companies, the role of debt collectors cannot be separated, in which debt collectors are third parties assisted by finance or leasing companies to resolve problem loans that cannot be handled by regular collectors. ${ }^{25}$ Indonesia itself is a state of law which demands an understanding that every action that gives rise to a certain event will have implications for certain legal consequences as well. Leasing as part of the types of agreements in civil relations cannot be separated from the existence of the principle of pacta sunt servanda. The agreement is essentially a law for the parties who make it. So that in the sale and purchase agreement using a good and correct Leasing financing mechanism, several elements must be included to provide guarantees related to legal certainty, namely (i) the identity of the debtor; (ii) specification of the object of goods purchased through a credit mechanism by the debtor; (iii) loan repayment period; (iv) provisions related to fines if the debtor is late in paying the monthly credit; (v) prohibition of partial or full transfer of rights and legal control to third parties; and (vi) choice of dispute resolution forum (mediation or court). ${ }^{26}$

Debtors who experience arrears in installments or bad credit, which will cause default problems. The consumer finance company acts to send warning letters (sumasi) several times to the debtor. However, if the

25 http.blogspot.com/ 2011/05/ Analisis-penggunaan-Debt-Collector.html) diakses pada tanggal 6 Desember 2018, pukul.15.00 WIB

26 Ibid. 
warning letter is ignored by the debtor, the finance company will take or confiscate the goods with the help of the Debt Collector. Currently in people's lives, it is often heard that there are cases of debt collection against debtors by creditors using debt collectors in collecting debts by coercion. Arrears who are unable to pay off their bills, debt collectors ordered by financing institutions for non-performing loans will take a number of goods, both movable and immovable as collateral. If the arrears have paid it, then the guarantee will be returned, but if it is not paid off of course the item will disappear. In addition, it is not uncommon for debt collectors to do so using threats and violence. ${ }^{27}$

The use of Debt Collectors in consumer finance companies is not prohibited as long as it is carried out in accordance with established procedures and does not violate existing norms and rules. However, in practice, debt collectors often confiscate vehicles belonging to problem creditors. Cases of forcible withdrawal of motorized vehicles by debt collectors can be categorized as criminal acts. Actually, regarding debt collectors who threaten to confiscate, debtors do not need to be afraid and worried about such threats because debt collectors have received authorization from creditors to collect debts and cannot forcibly confiscate the debtor's belongings. In principle, the confiscation of goods carried out by debt collectors against debtors who default can only be carried out on the basis of court decisions. If the debt collector continues to confiscate or forcibly take the debtor's belongings against the law, then you can report the debt collector to the police. ${ }^{28}$ Indeed, in the collection by debt collectors, these debt collectors search for problematic motorcycles on the side of the road that are often passed by the public or crowded places that are often visited by the public such as markets or shopping centers. In carrying out their duties, these debt collectors often ignore the principles of decency and propriety, and sometimes even lead to thuggery. If in practice the debt collectors continue to confiscate and forcibly take goods where the goods belong to the debtor, the debt collector's actions can be said to be against the law, therefore the debtor can report the debt collector to the police. Deeds of debt collectors who violate these rules can be subject to criminal sanctions in the form of threats in Article 362 of the Criminal Code (KUHP) regarding theft and/or if carried out with violence or threats of violence, they can also be snared using Article 365 of the Criminal Code. The texts of the two articles include: ${ }^{29}$

27 Prika Handayani dan Teddy Asmara. Pertanggungjawaban Pidana Debt Collector Yang Melakukan Tindak Pidana Perampasan Dalam Kredit Bermasalah. Jurnal Hukum Progresif Vol. 10 No. 2. 2019. pp 56-57. See also Saleha Mufida, FG Cempaka Timur, and Surryanto Djoko Waluyo. "Strategi Pemerintah Indonesia dalam Menangani Wabah Covid-19 dari Perspektif Ekonomi." Independen Vol. 1 No.2, 2020, pp. 121-130.

28 Ibid.

29 Kitab Undang - Undang Hukum Pidana (KUHP), Indonesian Criminal Code 
Article 362 of the Criminal Code:

Whoever takes something, wholly or partly belonging to another person, with the intention of unlawfully possessing it, is threatened with theft, with a maximum imprisonment of five years or a maximum fine of nine hundred rupiahs. (Barang siapa mengambil barang sesuatu, yang seluruhnya atau sebagian kepunyaan orang lain, dengan maksud untuk dimiliki secara melawan hukum, diancam karena pencurian, dengan pidana penjara paling lama lima tahun atau pidana denda paling banyak sembilan ratus rupiah.)

Article 365 paragraph (1) of the Criminal Code:

By a maximum imprisonment of nine years, theft which is preceded, accompanied or followed by violence or threats of violence, against a person with the intent to prepare or facilitate the theft, or in the case of being caught red-handed, to enable the escape of oneself or another participant, or to maintain control. stolen item. Diancam dengan pidana penjara paling lama sembilan tahun pencurian yang didahului, disertai atau diikuti dengan kekerasan atau ancaman kekerasan, terhadap orang dengan maksud untuk mempersiapkan atau mempermudah pencurian, atau dalam hal tertangkap tangan, untuk memungkinkan melarikan diri sendiri atau peserta lainnya, atau untuk tetap menguasai barang yang dicuri).

Therefore, it can be said that the liability of debt collectors in forcibly collecting debts and not in accordance with procedures is to use the criminal route. The behavior of debt collectors is still a serious problem that has not been handled. On the one hand, consumers feel disturbed by the actions of these debt collectors. On the other hand, debt collectors as representatives of banks and financial institutions are responsible for debt arrears that can harm banks and other financing institutions. The problem is, there are no clear boundaries and rules regarding the procedures for collection by a debt collector. Currently, there are only regulations for banks and their respective financing institutions. Actually, the behavior of debt collectors in the field is often not in accordance with things that have been previously agreed upon between creditors and debtors. If the treatment of debt collectors who are already at an alarming stage, for example, is making trouble, terrorizing both directly and over the phone, even threatening to kill the customer. Legally, the method of collection by debt collectors accompanied by threats, insults, and terror cannot be justified and of course has led to criminal acts. 
Widya Kurnia Sulistyowati

In Bank Indonesia Circular Letter No.7/60/DASP Year 2005 Chapter IV numbers 1 and 2 reads as follows: ${ }^{30}$

1. If in carrying out credit distribution activities the Issuer and/or Financial Acquirer cooperates with other parties outside the Issuer and/or Financial Acquirer, such as cooperation in marketing, billing, and/or system operation activities, the Issuer and/or Financial Acquirer must ensure that the procedures, mechanisms, procedures, and quality of the implementation of activities by other parties are in accordance with the procedures, mechanisms, procedures, and quality if the activities are carried out by the Issuer and/or the Financial Acquirer itself. Debt collector is a third party that connects creditors and debtors in terms of credit collection. The collection can only be done if the quality of the credit card bill is included in the category of doubtful or bad collectibility based on the collectibility used by the credit card industry in Indonesia.

2. In the event that the Issuer uses the services of another party in collecting Credit Card transactions, then: a. Billing by the other party can only be made if the quality of the Credit Card billing has been included in the category of doubtful or bad collectibility based on the collectibility criteria used by the Credit Card industry. in Indonesia, and the Issuer is obligated to guarantee that the collection by the other party, apart from being required to be carried out with due observance of the provisions in item 1, must also be carried out in a manner that does not violate the law.

From the two contents of the circular above, essentially it states that debt collectors as other parties, namely in this case as a third party from the leasing agency in charge of collecting bad loans from consumers are required to comply with all procedures provided by the leasing institution concerned and most importantly, the credit collection process is not carried out in ways that violate the law.

The ethics of collection by debt collectors, namely: debt collectors must comply with the ethics that have been regulated in Bank Indonesia Circular Letter No. 11/10/DASP dated April 13, 2009 Regarding the Operation of Card-Based Payment Instruments ("SEBI 2009") as amended by Circular Letter of Bank Indonesia Number 14/17/DASP dated June 7, 2012 Regarding Amendments to Circular Letter of Bank Indonesia Number 11/10/DASP concerning Implementation of CardBased Payment Instrument Activities and lastly amended by ("SEBI 2012”) Bank Indonesia Circular Letter Number 18/33/DKSP Year 2016 concerning Fourth Amendment to Bank Indonesia Circular Letter

30 Surat Edaran Bank Indonesia No.7/60/DASP Tahun 2005 
Number 11/10/DASP Date April 13, 2009 Regarding the Implementation of Card-Based Payment Instrument Activities. ${ }^{31}$

Basically, in determining the debtor's installment collection, the financial institution must comply with the principals of debt collection ethics. Creditors are required to guarantee that debt collection is carried out in accordance with Bank Indonesia regulations and applicable laws and regulations. Here are some ethics that must be owned by debt collectors who collect: ${ }^{32}$

1. Debt collectors have the identity of the Credit Card Issuer which is accompanied by a photo of the person concerned;

2. Billing is not carried out using threats, violence and/or actions that are embarrassing to the Credit Card Holder;

3. Billing is not done using physical or verbal pressure;

4. Billing is prohibited from being done to parties other than the Credit Card Holder;

5. Billing using communication facilities is prohibited from being carried out continuously which is disturbing;

6. Billing can only be made at the billing address or domicile of the Credit Card Holder;

7. Billing can only be made from 08.00 to 20.00 in the time area of the Credit Card Holder's address;

8. Billing outside the place and/or time mentioned above, can only be made on the basis of prior approval and/or agreement with the Credit Card Holder;

9. Credit Card collection using a collection service provider from a debt collector can only be done if the quality of the Credit Card billing has been classified as bad quality based on the collectibility criteria in accordance with Bank Indonesia regulations governing credit quality.

Buying a vehicle by paying in installments with the help of a finance company or multi-finance company is more attractive to consumers. Easier and faster procedures are the reason consumers prefer to apply for financing to multifinance. However, to maintain credit quality, the multi will make withdrawals of motorized vehicles from customers whose installment payments are in arrears and exceed the specified limit. Meanwhile, in carrying out the withdrawal process, there are procedures that must be obeyed by multifinance. ${ }^{33}$

Based on Law No.42 of 1999 concerning Fiduciary Guarantees ("Law No.42/1999"), Fiduciary is defined as a process of transferring

31 Tri Jata Ayu Pramesti, Panduan Hukum Menghadapi Debt Collectors, https://www.hukumonline.com/klinik/detail/ulasan/lt4d9d52b6c5d33/panduanhukum-menghadapi-idebt-collector-i diakses pada 17 September 2020

32 Ibid.

33 Handayani \& Teddy Asmara. Pertanggungjawaban Pidana Debt Collector Yang Melakukan Tindak Pidana Perampasan Dalam Kredit Bermasalah. Jurnal Hukum Responsif, Vol. 10 No. 2. 2019. p. 61. 
ownership rights to an object on the basis of trust, but the object is still in the control of the transferor. Fiduciaries are generally included in motor vehicle loan agreements or other movable objects and buildings that cannot be charged with Mortgage Rights. The imposition of a fiduciary guarantee on an object entitles the creditor as the fiduciary recipient to take advance payment of his receivables to the debtor of the fiduciary guarantee (debtor) (droit de preferren/preferred rights) (Article 27 paragraph (1) of Law No.42/1999) Because of the Preferred Rights owned by the Creditor, if the debtor/fiduciary provider breaks the promise, the debtor is obliged to surrender the object that is used as a fiduciary object in the context of carrying out the execution of the fiduciary guarantee. then the imposition of fiduciary guarantees must be carried out in two stages, namely: ${ }^{34}$

1. Fiduciary Object Imposition Stage The imposition stage means the process of making a Fiduciary Guarantee Deed which must be carried out before a notary in the Indonesian language (Article 5 paragraph (1) of Law No. 42/1999). This Fiduciary Guarantee Deed has perfect evidentiary power and explains that the parties have understood and understood the contents of the Fiduciary Guarantee Deed such as: the value of the guarantee, the value of the object used as a fiduciary object, etc., existing debts, debts that will arise in the future, execution execution, etc.

2. Fiduciary registration stage. The registration stage means the process of registering a fiduciary object to the Fiduciary Registration Office which is carried out at the domicile of the Fiduciary Giver (Articles 11 and 12 of Law No.42/1999). The registration of the fiduciary object is required to fulfill the principle of publicity and provide guarantees to third parties regarding the fiduciary object.

After the fiduciary registration is carried out, the Fiduciary Registration Office will then issue a Fiduciary Guarantee Certificate which has executorial power which has the same degree as a court decision that has permanent legal force. Fiduciary Guarantees for Financing Companies conducting Consumer Financing for Motor Vehicles with the Imposition of Fiduciary Guarantees ("PMK No. 130/2012") also stipulates that finance companies are prohibited from withdrawing motorized vehicle fiduciary collateral items if the Fiduciary Registration Office has not issued a Fiduciary Guarantee Certificate and submits it The confiscation of a fiduciary object without a Fiduciary Guarantee Certificate also has the potential to be charged with the provisions of Article 1365 of the Civil Code concerning Unlawful Acts or criminal acts of coercion and threats of confiscation as stipulated in Article 365 of the Criminal Code. D In the Criminal Code, it is clearly stated that the court has the right to execute. So if you want to take a

34 Ibid. 
guarantee, you must bring an Execution Determination Letter from the District Court. ${ }^{35}$

\section{CONCLUSION}

This study concludes that Legal Aid is a legal service provided by Legal Aid Providers free of charge to Legal Aid Recipients. As a result of the COVID-19 pandemic, many people cannot pay their installment bills, so debt collectors are forced to withdraw the debtor's belongings. Many people who are economically disadvantaged ask for legal assistance from the Legal Aid Institute. The form of legal protection for debtors who are affected by the spread of the COVID-19 outbreak, namely debtors can apply for restructuring and debtors get restructuring or financing in accordance with Article 5 and Article 6. once there was an incident of mass layoffs and resulted in a decrease in people's income, because the area was classified as a red zone and certainly implemented large-scale social restrictions. The criteria for debtors who meet the requirements for credit restructuring due to the COVID-19 pandemic will be assessed based on the credit quality of the debtor where before the COVID-19 pandemic the debtor has been declared in default, it will be taken into consideration for creditors whether or not to provide credit restructuring. And for criminal liability from the debt collector, if the debt collector is proven to have committed coercion and violence against debtors related to debt collection, the debt collector can be subject to criminal sanctions in Article 362 of the Criminal Code and 365 paragraph (1) of the Criminal Code.

\section{REFERENCES}

Afriandy, et.al. (2020). Panduan Bantuan Hukum Selama Pandemi Covid - 19. Jakarta: YLBHI.

Albanjari, F. R., Prihatin, R., \& Suprianto, S. (2021). Analisa Dampak Kebijakan Pemerintah Terhadap Kinerja Keuangan Bank Umum Syariah di Indonesia Pada Era Pandemi Corona Virus Disease19. Musyarakah: Journal of Islamic Economic (MJSE), 1(1), 9-19.

Aminah, A. (2020). Pengaruh Pandemi Covid 19 Pada Pelaksanaan Perjanjian. Diponegoro Private Law Review, 7(1), 10-16.

Atikah, I. (2018). Perusahaan Leasing dan Debt Collector Dalam Penagihan Kredit Macet Kendaraan Debitur. ADALAH, 2(8).

Bakarbessy, L., \& Anand, G. (2018). Buku Ajar Perikatan. Sidoarjo: Zifatama Jawara.

35 Ibid. 
Widya Kurnia Sulistyowati

Handayani, I. (2021). Pandemi Covid-19, Masyarakat Banyak Minta Bantuan Hukum Soal Debt Collector. https://www.beritasatu.com/nasional/733275/pandemi-covid19masyarakat-banyak-minta-bantuan-hukum-soal-debt-collector di akses pada Senin, 15 Februari 2021.

Handayani, P., \& Asmara, T. (2019). Pertanggungjawaban Pidana Debt Collector Yang Melakukan Tindak Pidana Perampasan Dalam Kredit Bermasalah. Hukum Responsif, 10(2).

Hardiansyah, H. (2021). Perlindungan Hukum Terhadap Debitur Yang Kesulitan Untuk Memenuhi Kewajiban dalam Perjanjian Kredit Akibat Pandemi Covid-19. Dinamika: Jurnal Ilmiah Ilmu Hukum, 27(3), 430-445.

Junaedi, U. A. (2020). Analysis of Covid-19 Impact for Law and Society. The Indonesian Journal of International Clinical Legal Education, 2(3), https://doi.org/10.15294/ijicle.v2i3.38330

219-234.

Kumala, R. D. M. (2020). Legal Analysis of Government Policy on Large Scale Social Restrictions in Handling Covid-19. The Indonesian Journal of International Clinical Legal Education, 2(2), 181-200.

Lincolin, A. (2004). Ekonomi Pembangunan. Yogyakarta: STIE YKPN.

Mufida, S., Timur, F. C., \& Waluyo, S. D. (2020). Strategi Pemerintah Indonesia Dalam Menangani Wabah Covid-19 dari Perspektif Ekonomi. Independen, 1(2), 121-130.

Muhammad, A. (2010). Hukum Perusahaan Indonesia. cet. ke-4 revisi. Bandung: PT. Citra Aditya Bakti.

Munandar, M. H. (2020). Analysis the effectiveness of tax relaxation due to Covid-19 pandemy on Indonesian economic defense. Lex Scientia Law Review, 4(1), 125-133.

Nugrahaningsih, W., \& Utami, I. W. (2021). Perlindungan Bagi Debitur Penerima Fasilitas Kredit Dimasa Pandemi Covid 19. Jurnal Indonesia Sosial Sains, 2(3), 484-493.

Philipus M. Hadjon. (1987). Perlindungan Bagi Rakyat Diindonesia, Surabaya: Bina Ilmu.

Pramesti, T. J. A. (2020). Panduan Hukum Menghadapi Debt Collectors, https://www.hukumonline.com/klinik/detail/ulasan/lt4d9d52b6c5 d33/panduan-hukum-menghadapi-idebt-collector-i diakses pada 17 September 2021

Putra, A., \& Saraswati, D. (2020). Bank dan Lembaga Keuangan Lainnya. Surabaya: CV. Jakad Media Publishing.

Rosita, R. (2020). Pengaruh pandemi Covid-19 terhadap UMKM di Indonesia. Jurnal Lentera Bisnis, 9(2), 109-120.

Salters, S. (2021). Debt-Collection Reforms Draw Congressional Focus Post-COVID. American Bankruptcy Institute Journal, 40(7), 8-55. 
Sina, P. G. (2020). Ekonomi Rumah Tangga Di Era Pandemi Covid19. Journal of Management: Small and Medium Enterprises (SMEs), 12(2), 239-254.

Sukerta, I. M. R., Budiartha, I. N. P., \& Arini, D. G. D. (2021). Restrukturisasi Kredit terhadap Debitur Akibat Wanprestasi Karena Dampak Pandemi Covid-19. Jurnal Preferensi Hukum, 2(2), 326-331.

Usanti, T. P., \& Shomad, A. (2017). Hukum Perbankan. Jakarta: Kencana.

[...] http.blogspot.com/2011/05/Analisis-penggunaan-DebtCollector.html) diakses pada tanggal 6 Desember 2018, pukul.15.00 WIB.

\section{Laws and Regulations}

Undang - Undang Dasar Negara Republik Indonesia Tahun 1945

POJK (Peraturan Otoritas Jasa Keuangan) Nomor 11/POJK.03/2015 tentang Ketentuan Kehati-Hatian Dalam Rangka Stimulus Perekonomian Nasional Bagi Bank Umum

Kitab Undang - Undang Hukum Pidana

Surat Edaran Bank Indonesia No.7/60/DASP Tahun 2005 


\section{"What can be added to the happiness of a man who is in health, out of debt, and has a clear conscience?"}

\section{Adam Smith}

\section{Conflicting Interest Statement}

All authors declared that there is no potential conflict of interest on publishing this article.

\section{Funding}

None

\section{Publishing Ethical and Originality Statement}

All authors declared that this work is original and has never been published in any form and in any media, nor is it under consideration for publication in any journal, and all sources cited in this work refer to the basic standards of scientific citation.

Cite this article as:

Sulistyowati, W. K. (2021). Implementation of Legal Aid to Debtors Due to Arrears in Motor Vehicle Installments Executed by Debt Collectors as Impact of the Covid-19 Pandemic. The Indonesian Journal of International Clinical Legal Education, 3(4), 445-464. https://doi.org/10.15294/ijicle.v3i4.48295 